\title{
Sağlık Teknikerliği Programı Öğrencilerinin Nükleer Fizik Kavramları ile ilgili Kavramsal Anlama Düzeylerinin Belirlenmesi
}

\author{
Erdoğan Özdemir ${ }^{1 *}$, Onur Yarar ${ }^{2}$ \\ 1*Sivas Cumhuriyet Üniversitesi, Sağlı Hizmetleri Meslek Yüksekokulu, Optisyenlik Programı, Sivas, Türkiye, (ORCID: 0000-0001-7943-8002), \\ erdoganozdemir@cumhuriyet.edu.tr \\ 2 İstanbul Okan Üniversitesi, Sağlık Bilimleri Fakültesi, Sağlık Yönetimi Bölümü, İstanbul, Türkiye (ORCID: 0000-0001-9543-6891), \\ onur.yarar@okan.edu.tr
}

(Illk Geliş Tarihi 12 Şubat 2021 ve Kabul Tarihi 4 Nisan 2021)

(DOI: 10.31590 /ejosat.879306)

ATIF/REFERENCE: Özdemir, E., Yarar, O. (2021). Sağlık Teknikerliği Programı Öğrencilerinin Nükleer Fizik Kavramları ile ilgili Kavramsal Anlama Düzeylerinin Belirlenmesi. Avrupa Bilim ve Teknoloji Dergisi, (23), 465-474.

$\ddot{O} z$

Radyoterapi, nükleer tıp, tıbbi görüntüleme, ameliyathane hizmetleri teknikerliği meslekleri radyasyon teknolojilerini kullandıkları için nükleer fizik ile doğrudan ilişkili olan mesleklerdir. Bu araştırmada, bu programlarda öğrenim gören öğrencilerin nükleer fizik kavramları ile ilgili kavramsal anlama düzeyi araştırılmıştır. Araştırmada karma model kullanılmıştır. Araştırmanın örneklemini 100 öğrenci oluşturmaktadır. Veriler "Kavram Yanılgısı Belirleme Testi”" ve "Yarı-Yapılandırılmış Görüşmeler" ile toplanmıștır. Öğrencilerin testteki ortalama başarı puanı (14.93) "düşük başarı" kategorisinde değerlendirilmiştir. Öğrencilerin tüm kavramlarda "diğer yanıt" (boş bırakılan ve kavramsal olarak anlamlı olmayan yanıtlar) kategorisinde toplanma yüzdesi "doğru kavram" ve "kavram yanılgısı" kategorilerinde toplanma yüzdesinden fazladır. Bu sonuç, öğrencilerin nükleer fizik kavramları ile ilgili yeterli kavramsal anlamaya sahip olmadıkları şeklinde yorumlanmıştır. Ayrıca araştırmada tespit edilen nükleer fizik ile ilgili kavram yanılgıları detaylı olarak incelenmiştir.

\section{Determination of Conceptual Understanding Levels of Health Technician Program Students on Nuclear Physics Concepts}

\begin{abstract}
Radiotherapy, nuclear medicine, medical imaging, operating room technician professions are the professions that are directly related to nuclear physics because they use radiation technologies. In this study, the conceptual understanding level of students studying in these programs about nuclear physics concepts was investigated. The mixed model was used in this research. The sample of the study consists of 100. The data were collected through "Misconception Determination Test" and "Semi-Structured Interviews". The achievement average point (14.93) of the students who participated in the study were evaluated in the "low success" category. In addition, the percentage of students gathering in the other answer (blank and not conceptually meaningful answers) category in all concepts is more than the percentage of "correct concept" and "misconception" categories. This result was interpreted as that students did not have a sufficient conceptual understanding of nuclear physics concepts. In addition, misconceptions about nuclear physics which were detected in this research were discussed in detail.
\end{abstract}

Keywords: Physics education, Nuclear physics education, Conceptual understanding, Misconception.

*Sorumlu Yazar: erdoganozdemir_1979@hotmail.com 


\section{Giriş}

Fizik temel bir bilimdir. Bu nedenle, birçok meslek ile doğrudan ilişkilidir (Özdemir, Çoramık ve Ürek, 2020). Radyoterapi, nükleer tıp, tıbbi görüntüleme, ameliyathane hizmetleri fizik ile doğrudan ilişkili olan sağlık teknikerliği programlarındandır. Radyoterapi teknikeri, hastaların röntgeninin çekilmesinde ve hastalara ışın tedavisi uygulanmasında görev alır. Nükleer tıp teknikeri, tıpta kullanılan radyoaktif maddeleri hazırlar. Tıbbi görüntüleme teknikeri, röntgen ve nükleer manyetik rezonans (NMR) gibi görüntüleme cihazlarını kullanır. Ameliyathane Hizmetleri teknikeri ise ameliyathaneleri ameliyata hazır hale getirir ve ameliyatta yardımcı personel olarak çalışır. $\mathrm{Bu}$ sağlık teknikerliği mesleklerinin ortak özelliklerinden biri, çalışma ortamlarında radyasyon (1şıma) teknolojisinin kullanılmasıdır.

Türkiye'de radyoterapi, nükleer tıp, tıbbi görüntüleme, ameliyathane hizmetleri teknikerleri önlisans düzeyinde eğitim veren yüksekokullarda iki yıllık eğitim ile yetiştirilmektedir (Yüksel, 2018). Radyasyon teknolojileri teşhiste ve tedavide sık kullanılmaktadır. $\mathrm{Bu}$ nedenle bu programlarda öğrenim gören ögrencilerin sağlık alan bilgisinin yanı sıra temel düzeyde fizik bilgisine de sahip olması amaçlanmaktadır ve bu programlarda temel fizik, nükleer tıp laboratuvarı, nükleer fizik, radyasyondan korunma ve radyasyon güvenliği gibi derslere yer verilmektedir (Palac1, Günay ve Yarar, 2018).

Sağlık teknikerliği programlarında öğrenim gören bu öğrencilerin mesleklerinde radyasyon teknolojilerini kullanacak olmaları radyasyonun kaynaklarından birini oluşturan nükleer fizik kavramlarını doğru öğrenmelerini önemli hale getirmektedir.

Birçok bilim öğretimi araştırması öğrencilerin kavramsal anlamalarına odaklanmıştır (Ausubel, 1968; Novak, 1993). Öğrencilerin kavramsal anlama düzeyi ile ilgili araştırmalar, öğrencilerin bilimsel kavramlar yerine çeşitli alternatif kavramlara sahip olduklarını göstermektedir (Halim, Finkenstaedt, Olsen, Gere ve Shultz, 2018). Kavram yanılgıs1 olarak da adlandırılan bu alternatif kavramlar, öğrenciler tarafından doğru kabul edilen ve kişisel deneyimler ve gözlemler ile kazanılan görüşlerden oluşmaktadır (Gilbert, 1977; Palmer, 1999). Alanyazın incelendiğinde fizik kavramları ile ilgili kavram yanılgılarını belirlemek için birçok araştırmanın yapıldığı görülmektedir. Bu araştırmaların büyük bölümü fiziğin alt dalları olan mekanik, elektrodinamik, optik ve termodinamik ile ilgilidir. Alanyazında nükleer fizik ile ilgili kavram yanılgılarını belirlemek için yapılmış az sayıda araştırmaya rastlanmıştır (Neumann, 2014). Aşağıda, bu araştırmalar ve sonuçları ilköğretim, ortaöğretim ve üniversite düzeyine göre ayrı ayrı sunulmuştur.

Klaassen, Eijkelhof ve Lijnse (1990) ilköğretim öğrencileri ile bir araştırma gerçekleştirmiştir. Araştırmada öğrencilerin radyoaktivite ile ilgili kavramları birbirine karıştırdıkları ifade edilmiştir. Öğrencilerin radyoaktivite, radyoaktif materyal ve radyasyon kavramlarını birbiri yerine kullandıkları tespit edilmiştir. Bu araştırmada öğrencilerin lazer ve ultraviyole ışınını radyoaktivite olarak tanımladıkları ifade edilmiştir. Araştırmada Öğrenciler Chernobyl kazası sırasında reaktörden sıan radyasyonun rüzgar ile taşındığını, yağmur ile yeryüzüne indiğini, su ile de meyve ve sebzelere geçtiğini açıklamıştır (Eijkelhof ve Millar, 1988). Bu meyve ve sebzeleri yiyen insanların ise vücutlarında radyasyon taşımaya başladı̆̆ı belirtilmiştir.
Araştırmada elde edilen başka bir bulgu ise öğrencilerin radyasyon kirliliğini yalnızca radyasyon kavramı ile açıklamalarıdır. Radyasyon öğrenciler için hastalığı çağrıştıran bir kavramdır. Ayrıca araştırmada öğrencilerin radyasyon ile korkuyu özdeşleştirdiği belirtilmiştir. Millar, Klaassen ve Eijkelhof (1990) ise ilköğretim öğrencileri ile bir araştırma gerçekleştirmiştir. Araştırmada öğrenciler radyasyon ve radyoaktif materyal kavramlarını bir kaynaktan bir şekilde yayılan ve çevresindeki diğer canlıları etkileyen tek bir kavram olarak tanımlamıştır. Öğrencilere göre bu kavramın etkisi uzaklık ile azalmaktadır, canlılar için tehlikelidir ve bir canlı tarafından soğurulduktan sonra tekrar yayılabilir. Riesch ve Westphal (1975), ilköğretim öğrencileri ile gerçekleştirdiği araştırmasında öğrencilerin radyasyon ve radyoaktif materyal kavramlarını aynı anlamda kullanılmasının aktivite ve doz kavramları ile ilgili tatmin edici açıklamalar yapamamalarına neden olduğunu ifade etmiştir. Neumann (2014), ilköğretim öğrencilerinin radyasyon kavramı ile ilgili algı düzeylerini araştırmıştır. Araştırmada öğrencilerin radyasyon ile ilgili düşüncelerini nükleer radyasyonun şekillendirdiği sonucuna ulaşılmıştır. Radyasyon sözcüğünün öğrencilerde ağırlıklı olarak olumsuz çağrışım yaptığı ve öğrencilerin radyasyonu uzak durulması, kaçınılması gereken bir şey olarak düşündükleri anlaşılmıştır. Araştırmada öğrencilerin doğal radyasyon fikrine aşına olmadıkları, birçok öğrencinin radyasyonu genellikle yapay ve insan yapımı bir şey olarak tanımladıkları vurgulanmıştır. Ayrıca araştırmada hiçbir öğrencinin radyasyonun tıp ve nükleer santral dışında teknolojide kullanımına değinmediği ifade edilmiştir.

Millar ve Gill (1996) ortaöğretim öğrencileri ile gerçekleştirdiği araştırmasında, öğrencilerin radyoaktif ışıma (irradiation) ve radyoaktif bulaşma (contamination) kavramları ile ilgili kavramsal anlama düzeylerini araştırmıştır. Araştırmada yalnızca küçük bir öğrenci grubunun bu iki kavramı doğru açıklayabildikleri ifade edilmiştir. Öğrencilerin büyük bir bölümünün bu kavramları birbiri ile karıştırdığı ve bu kavramlar ile ilgili çeşitli kavram yanılgılarına sahip olduğu anlaşılmıştır. Araştırmada öğrencilerin radyoaktivite ile ilgili kavramları birbiri yerine kullanmalarına bağlı olarak oluşan kavram yanılgıları şu şekilde sıralanmıştır; (i) Radyoaktif ışıma sırasında kaynaktan çevreye radyoaktif materyal yayılır. (ii) Radyoaktivite yayılabilir. (iii) Radyoaktif kaynak elektrik alan manyetik alan gibi radyoaktif bir alana sahiptir. (iv) Radyasyon rüzgar ile taşınır. (v) Radyoaktivite rüzgar ile taşınır. (vi) Radyasyon atmosferi kirletir. Cooper, Yeo ve Zadnik (2003) ortaöğretim öğrencilerinin nükleer fizik ile ilgili konularda bilgi düzeyini araştırmıştır. 78 öğrencinin katıldığı araştırmada içerik (çevresel radyasyon, sağlık alanında nükleer uygulamalar ve nükleer güç) tabanlı öğretimin öğrencilerin nükleer radyasyon ve nükleer radyasyonun kullanımı ile ilgili düşüncelerindeki değişime etkisi araştırılmıştır. Öğretim sonrasında öğrencilerin nükleer radyasyon konusundaki düşüncelerinde değişiklik olmasına rağmen nükleer enerji konusundaki korkularının ve kaygılarının devam ettiği tespit edilmiştir. Öğrencilerin nükleer enerji ile ilgili korkularının radyoaktif madde sizıntısından mı yoksa radyasyonun suya veya havaya salınmasından $\mathrm{m}$ ı kaynaklandı ğ Araştırmacılar bu durumun öğrencilerin radyoaktivite ve radyasyon kavramlarını birbiri yerine kullanmasından kaynaklandığını düşünmüştür. Buna ek olarak öğrencilerin çoğunun öğretim sonrasında hala iyonlaştırıcı radyasyonun insan dokusu üzerindeki etkileri ile ilgili sınırlı bilgiye sahip oldukları anlaşılmıştır. Tezcan ve Erçoklu (2010) ortaöğretim öğrencilerinin katıldığı araştırmada öğrencilerin nükleer fizik ile ilgili birçok kavram yanılgısına sahip olduğunu tespit etmiştir. $\mathrm{Bu}$ 
araştırmada öğrencilerin radyoaktiflik, yarılanma süresi, izotoplar, çekirdek enerjisi, atom ve hidrojen bombası kavramları ile ilgili kavram yanılgıları belirlenmiştir. Araştırmada öne çıkan kavram yanılgıları şu şekildedir; (i) Yarılanma süresi maddenin başlangıçtaki miktarına, sıcaklığa, maddenin fiziksel haline bağlıdır. (ii) Atom bombası hidrojen bombasından daha güçlüdür. Benzer bulgulara Morgil, Yılmaz ve Uludağ (2004) ortaöğretim öğrencilerinin katılımı ile gerçekleştirdikleri araştırmada rastlamıştır. Araştırmada öğrencinin özellikle radyoaktif bozunma ve yarılanma süresi ile ilgili doğru yanıt yüzdelerinin düşük olduğu tespit edilmiştir. Ayrıca araştırmada öğrencilerin radyoaktif maddelerin aktiviteleri, izotop kavramı, alfa ve beta ışınları ile ilgili eksik bilgileri olduğu belirlenmiştir. Buna ek olarak öğrencilerin yarılanma süresi ile radyoaktif maddenin kütlesi arasında bir ilişski olduğunu düşündükleri tespit edilmiştir. Nakiboğlu ve Tekin (2006) ortaöğretim öğrencilerinin nükleer kimya kavramları ile ilgili kavramsal anlama düzeyini araştırmıştır. Ortaöğretim öğrencilerinin katıldığı araştırmada öğrencilerin nükleer kimya kavramlarını anlama düzeyinin düşük olduğu saptanmıştır. Ayrıca araştırmada öğrencilerin birçok kavram yanılgısına sahip olduğu tespit edilmiştir. Belirlenen kavram yanılgılarının bir bölümü şu şekildedir; (i) Radyoizotoplar yalnızca enerji elde etmek için kullanılır. (ii) Radyoaktif bozunma düzeyi atomun fiziksel özelliklerine ve sıcaklığına bağlıdır. Mavi (2008) öğrencilerin nükleer fizik ile ilgili kavram yanılgılarını belirlemek için ortaöğretim öğrencileri ile bir araştırma gerçekleştirmiştir. Ortaöğretim öğrencileri ile gerçekleştirilen araştırmanın bulgularına göre öğrencilerin nükleer fizik kavramları ile ilgili kavramsal anlama düzeyi düşüktür. Araştırmada tespit edilen kavram yanılgıları şu şekildedir; (i) Doğal radyoaktivite yağmur, kar, basınç ve rüzgar gibi fiziksel koşullardan etkilenir. (ii) Radyasyona maruz kalan canlılar radyoaktif özellik kazanır. Yalçın ve Kılıç (2005) ortaöğretim öğrencilerinin nükleer fizik ile ilgili kavram yanılgılarını ve bu kavram yanılgılarının oluşmasında ders kitaplarının payını araştırmıştır. Araştırma sonucunda ders kitaplarında öğrencilerin sahip olduğu kavram yanılgılarının bir bölümünü destekleyen ifade ve resimlere rastlanmıştır. Araştırmada öğrencilerin bir bölümünün nükleer reaksiyonları değerlik elektronlarının değişimi ile açıkladıkları tespit edilmiştir. Ayrıca araştırmada bazı öğrenciler, röntgen çekiminde kullanılan X-ışınlarının radyoaktif tepkimeler sonucu açığa çıktığını ifade etmiştir. Araştırmada öğrencilerin radyoaktiviteye karşı olumsuz bir algılarının olduğu belirtilmiştir. Öğrencilerin doğada radyoaktif madde olmadığını, radyoaktif maddelerin tamamının laboratuvar ortamında sentezlendiğini düşündükleri tespit edilmiştir. Araştırmada radyoaktif bir maddenin yarı ömür süresi sonunda radyoaktif özelliğini kaybettiği düşüncesinin yaygın olduğu vurgulanmıştır. Tüm bunlara ek olarak öğrencilerin radyoaktif maddelerin işlenerek radyoaktif özelliğini kaybetmesinin mümkün olduğunu düşündükleri ifade edilmiştir. Neumann ve Hopf (2012), ortaöğretim öğrencilerinin radyasyon ile ilgili düşüncelerini belirlemek için bir araştırma gerçekleştirmiştir. Bu araştırmada tespit edilen kavram yanılgıları şu şekildedir; (i) Doğal radyasyon yoktur. (ii) Işık radyasyondan farklıdır. (ii) Tüm elektrikle çalışan cihazlar zararlı radyasyon yayar. (ii) Birçok çevresel problemin kaynağı radyasyondur. (iv) Radyasyon yaşayan canlılar tarafindan yayılır. Araştırma sonuçlarına göre ögrencilerin çoğu iyonize olmayan radyasyonun potansiyel riskleri hakkında yeterli bilgiye sahip değildir ve ögrenciler cep telefonları tarafindan yayılan radyasyonun iyonize olmayan radyasyon olduğunu bilmemektedir.
Prather (2005) üniversite öğrencilerinin radyasyon ve radyoaktivite konularını öğrenirken yaşadıkları güçlükleri araştırmıştır. Araştırmada öğrencilerin radyoaktif kararsızlığı ve bozunmayı atomun yük durumuna ve elektronun, protonun ve nötronun enerji, hareket ve kuvvet açısından etkileşimine bağladıkları anlaşılmıştır. Bu öğrenciler radyoktif 1şımayı kararsız bir durumdaki elektronun kararlı hale geçmek için foton yayınlaması durumu ile açıklamıştır. Kaczmarek, Bednarek ve Wong (1987) üniversite öğrencileri ile gerçekleştirdikleri araştırmada ikinci sınıfta öğrenim gören birçok tıp öğrencisinin bir röntgen odası içindeki nesnelerin röntgen çekimi sonrasında ışıma yaptığına inandıklarını belirlemiştir. Ayaz, Karakaş ve Sarıkaya (2016) üniversite öğrencilerinin nükleer enerji kavramı ile ilgili düşüncelerini belirlemek için bir araştırma gerçekleştirmiştir. Araştırmada öğrencilerin radyasyonu iyonlaştırıcı ve iyonlaştırıcı olmayan radyasyon olarak ikiye ayırmadıkları bunun yerine radyasyonu sşın olarak tek bir kavramla açıklama eğiliminde oldukları ifade edilmiştir. Araştırmada öğrencilerin radyasyonun zararı olarak radyasyonun kanser yapma özelliğini vurguladıkları, radyasyonun genetik etkilerinden ve görme bozukluklarına yol açmasından söz etmedikleri ifade edilmiştir. Yıldırım ve Kurt (2018) ortaöğretim ve önlisans öğrencilerinin radyasyon güvenliği bilgi düzeyini ve tutumunu araştırmıştır. Araştırma sonucunda araştırmaya katılan öğrencilerin radyasyon güvenliği bilgi düzeyinin düşük olduğu belirlenmiştir. Ön lisans öğrencilerinin radyasyon güvenliği bilgi düzeyinin ortaöğretim öğrencilerinin radyasyon güvenliği bilgi düzeyine göre daha yüksek olduğu fakat ön lisan ve ortaöğretim öğrencilerinin radyasyondan korunma tutumları arasında bir farklılık olmadığ 1 sonucuna ulaşılmştır. Bu sonuç araştırmacılar tarafından öğrencilerin radyasyon güvenliği tutumunun ön lisans düzeyindeki meslek eğitimi ile değişmediği şeklinde yorumlanmıştır.

İlgili alanyazın incelendiğinde nükleer fizik kavramları ile ilgili ilköğretim ve ortaöğretim düzeyindeki araştırmaların üniversite düzeyindeki araştırmalara göre daha fazla olduğu ve öğrencilerin öğretiminin her kademesinde nükleer fizik kavramlarını öğrenmede güçlük çektiği anlaşılmaktadır.

$\mathrm{Bu}$ araştırmada, alanyazındaki nükleer fizik kavram yanılgıları ile ilgili araştırmalardan farklı olarak sağlık teknikerliği programı öğrencilerinin nükleer fizik kavramları ile ilgili kavramsal anlama düzeyi araştırılmıştır. Araştırmada şu problem cümlelerine yanıt aranmıştır: Sağlık teknikerliği programı öğrencilerinin nükleer fizik kavramları ile ilgili kavramsal anlamaları ne düzeydedir? Sağlık teknikerliği programı öğrencilerinin nükleer fizik kavramları ile ilgili kavram yanılgıları nelerdir?

\section{Materyal ve Metot}

Bu bölümde araştırma modeli, örneklem, ölçme araçları ve verilerin analizi açıklanmıştır.

\subsection{Araștırma Modeli}

$\mathrm{Bu}$ araştırmada öğrencilerin kavramsal anlama düzeyini belirlemek için karma model kullanılmıştır. Bu modelde nicel ve nitel veriler bir arada kullanılır (Greene, Caracelli ve Graham, 1989). Bu araştırmada karma modelin tercih edilmesinin nedenlerinden biri, araştırmalarda yalnızca nitel veya yalnızca nicel verilerin kullanılmasına bağlı olarak ortaya çıkan geçerlilik sorununun üstesinden gelmektir. Araştırmada karma modelin tercih edilmesinin bir diğer nedeni ise öğrencilerin nükleer fizik 
ile ilgili kavramsal anlama düzeylerinin geniş bir resmini elde edebilmektir (Johnson, Onwuegbuzie ve Turner, 2007). Araştırmanın örneklemi uygun örnekleme yöntemi ile belirlenmiştir. Araştırmada veriler "Kavram Yanılgısı Belirleme Testi" ve "Yarı Yapılandırılmış Görüşmeler" ile toplanmıştır. Test verilerinin analizinde betimsel analiz kullanılmıştır.

\subsection{Araştırmanın Örneklemi}

Araştırmanın örneklemi uygun örnekleme yöntemi ile belirlenmiştir. Bu yöntemde örneklem seçiminde hem örneklemin kolay ulaşılabilir olmasına hem de örneklemde yer alan katılımcıların araştırmaya katılmak için gönüllü olmasına dikkat edilir. $\mathrm{Bu}$ yönteme göre belirlenen örneklemi bir üniversitenin sağlık hizmetleri meslek yüksekokulunun Radyoterapi, Nükleer Tıp, Tıbbi Görüntüleme, Ameliyathane Hizmetleri programlarında öğrenim görmekte olan 100 öğrenci oluşturmuştur. Araştırmaya katılan tüm öğrenciler ikinci sınıf öğrencisidir ve nükleer fizik veya radyasyondan korunma derslerini başarı ile tamamlamıştır. Araştırmaya katılan öğrencilerin \%3’ü nükleer tıp teknikerliği, \%58'i tıbbi görüntüleme, \%16's1 radyoterapi ve \%23'ü ameliyathane hizmetleri programı öğrencisidir. Öğrencilerin \%63’ü erkektir. \%37'si ise kadındır. Öğrencilerin yaşları 19-40 arasında değişmektedir.

\section{2. Ölçme Araçları}

Araştırmada veri toplama aracı olarak "Kavram Yanılgısı Belirleme Testi" ve "Yarı Yapılandırılmış Görüşmeler" kullanılmıştır.

\subsubsection{Kavram Yanılgısı Belirleme Testi}

"Kavram Yanılgısı Belirleme Testi" Yumuşak, Maraş ve Şahin (2016) tarafindan geliştirilmiştir. Ölçme aracı 18 soru içermektedir. Her bir soru iki aşamadan oluşmaktadır. Birinci aşamada nükleer fizik ile ilgili bir ifadeye ve bu ifade için doğru veya yanlış şeklinde iki seçeneğe yer verilmiştir. İkinci aşamada ise seçilen yanıtın nedeni sorulmaktadır ve bu soru için dört seçenek verilmiştir. Beşinci seçenek ise verilen seçenekler dışında bir görüşü olan katılımcıların görüşlerini yazmaları için boş bırakılmıştır. Testte yer alan beş soru radyoaktif materyaller $(1,2,5,8,10)$, bir soru radyoaktivite $(12)$, iki soru radyasyon $(4,11)$, iki soru çekirdek reaksiyonları $(7,16)$, bir soru yarılanma süresi (9), beş soru radyoaktif 1şımalar $(3,6,13,14,15)$ iki soru çekirdek reaksiyonları $(17,18)$ ile ilgilidir. Yumuşak vd. (2016), testin KR20 ortalama güvenilirlik katsayısını .69 , ortalama madde güçlük indeksini ise .45 olarak hesaplamıştır.

\subsubsection{Yarıyapılandırılmış Görüşsmeler}

"Yarı Yapılandırılmış Görüşmeler" için yarı yapılandırılmış görüşme formu hazırlanmıştır. Formun hazırlanması için ilk olarak "Kavram Yanılgısı Belirleme Testi" verileri analiz edilmiştir. Analiz sonuçları doğrultusunda yarı yapılandırılmış görüşme formunda radyoaktif materyal, radyoaktivite, radyasyon, yarı ömür, radyoaktif ışınlar ve çekirdek tepkimeleri konuları için birer soruya yer verilmiştir. $\mathrm{Bu}$ sorular, "Kavram Yanılgısı Belirleme Testi” bulgularında ön plana çıkan kavram yanılgıları ile ilgilidir. Yarı yapılandırılmış görüşme için oluşturulan taslak form altı sorudan oluşmaktadır.

Taslak form bir nükleer fizik ve bir de fizik eğitimi uzmanı tarafindan incelenmiştir. Uzman görüşleri doğrultusunda düzenlenen form son haline getirilmiştir.
Görüşme yapılan dört öğrenci ise örneklemde yer alan her bir teknikerlik programından bir öğrenci olacak şekilde rastgele seçilmiştir. $\mathrm{Bu}$ dört öğrenci ile yarı yapılandırılmış görüşme formu kullanılarak görüşme yapılmıştır. Bir öğrenci ile yapılan görüşme ortalama 20-25 dakika sürmüştür. Görüşmeler öğrencilerden izin alınarak ses kayıt cihazı ile kaydedilmiştir.

\subsection{Verilerin Analizi}

Araştırma verileri başarı düzeyi için analiz, kavramsal anlama düzeyi için analiz ve kavram yanılgısı için analiz olmak üzere üç başlık altında analiz edilmiştir.

\subsubsection{Başarı Düzeyi için Analiz.}

Araştırmada veri toplama aracı olarak kullanılan test iki aşamalı bir testtir. Bu nedenle öğrencilerin teste vermiş olduğu yanıtlar birçok kombinasyon oluşturmaktadır. $\mathrm{Bu}$ tür testlerin değerlendirilmesinde öğrencinin birinci aşamayı ve ikinci aşamayı doğru yanıtlamasına bağlı olarak puan aldığı bir derecelendirme ölçeğinin kullanılması önerilmektedir (Karataş, Köse ve Coşkun, 2003). Bu araştırmada, "Kavram Yanılgısı Belirleme Testi" verilerinin betimsel istatistik sonuçları aşağıdaki değerlendirme kriterlerine göre yapılmıştır.

Tablo 1. İki Aşamalı Test Derecelendirme Ölçeği

\begin{tabular}{ll}
\hline Değerlendirme Kriteri & Puan \\
\hline Doğru Yanıt-Doğru Yanıt & 3 \\
\hline Yanlış Yanıt -Doğru Yanıt & 2 \\
\hline Doğru Yanıt- Yanlış Yanıt & 1 \\
\hline Yanlış Yanıt-Yanlış Yanıt & 0 \\
\hline
\end{tabular}

Ölçek puanlama kriterlerine göre bir sorunun her iki aşamasını doğru yapan öğrencilere 3 , birinci aşamasını yanlış ikinci aşamasını doğru yapan öğrencilere 2, birinci aşamasını doğru ikinci aşamasını yanlış yapan öğrencilere 1, her iki aşamasını yanlış yapan öğrencilere ise 0 puan verilmiştir (Karataş vd., 2003). Bu durumda testteki her bir soru için alınabilecek en yüksek puan " 3 " ve testin bütününden alınabilecek en yüksek puan " 54 ” tür.

Öğrencilerin testin herbir sorusundan ve testin bütününden aldıkları puanlar öğrenci başarısı açısından üç kategoriye ayrılarak değerlendirilmiştir. Buna göre bir soru için 0.0-1.0 puan aralığ1 "düşük düzey başarı", 1.1-2.0 puan aralığ1 "orta düzey başarı", 2.1-3.0 puan aralığı ise "üst düzey başarı" olarak kategorize edilmiştir. Ayrıca testin bütünü için 0-18 puan aralığ "düşük düzey başarı", 19-36 puan aralığ1 "orta düzey başarı" ve 37-54 puan aralığ “"üst düzey başarı” olarak kategorize edilmiştir.

\subsubsection{Kavramsal Anlama Düzeyi için Analiz}

"Kavram Yanılgisı Belirleme Testi”nin her bir sorusuna öğrencilerin vermiş olduğu yanıtların oluşturduğu kombinasyonlar "doğru kavram", "kavram yanılgısı" ve "diğer yanıt" olarak kategorize edilmiştir. Tablo 2'de yanıtların bu şekilde kategorilere ayrılmasının nasıl yapıldığı açıklanmıştır. 
Tablo 2. Kavramsal kategorilerin oluşturulmasına bir örnek: Test'in 1. sorusu için kavramsal kategorilerin oluşturulması

Soru 1: Radyoaktif bir maddeyi, fiziksel ve kimyasal birtakım işlemlere tabi tutarak bu maddenin radyoaktif olma özelliğini ortadan kaldırmak mümkündür." ifadesi hakkında ne düşünüyorsunuz?

a. Doğru bir ifadedir. b. Yanlış bir ifadedir.

Seçtiğiniz cevabın nedeni aşağıdakilerden hangisidir?

a. Radyoaktif olmayan bir madde ile tepkimeye sokulursa radyoaktif özelliğini kaybeder.

b. Çok yüksek sıcaklığa maruz bırakılan radyoaktif bir madde radyoaktif olma özelliğini kaybeder.

c. Toprak altına gömülen radyoaktif bir madde radyoaktif olma özelliğini kaybeder.

d. Radyoaktif olma özelliği atomun çekirdeğindeki durumlara bağlı olduğundan fiziksel ve kimyasal yöntemlerle ortadan kaldırılamaz.

\begin{tabular}{|c|c|c|}
\hline Kategori & I. Aşama Yanıt & II. Aşama Yanıt \\
\hline Doğru Kavram & $\mathrm{b}$ & $\mathrm{d}$ \\
\hline $\begin{array}{l}\text { I. Kavram } \\
\text { Yanılgis1 }\end{array}$ & $\mathrm{a}$ & $\mathrm{a}$ \\
\hline Diğer Yanıt* & $\mathrm{b}$ & \\
\hline $\begin{array}{l}\text { II. Kavram } \\
\text { Yanılg1s1 }\end{array}$ & $\mathrm{a}$ & $\mathrm{b}$ \\
\hline Diğer Yanitr & $\mathrm{b}$ & \\
\hline $\begin{array}{l}\text { III. Kavram } \\
\text { Yanılgis1 }\end{array}$ & $\mathrm{a}$ & $\mathrm{c}$ \\
\hline Diğer Yanitr & $\mathrm{b}$ & \\
\hline Diğer Yanıt & Boş & $\begin{array}{l}\text { Herhangi bir seçenek } \\
\text { işaretlenmiş. }\end{array}$ \\
\hline Diğer Yanıt & $\begin{array}{l}\text { Herhangi bir seçenek } \\
\text { işaretlenmiş. }\end{array}$ & Boş \\
\hline
\end{tabular}

*Sorunun iki aşamasına verilen yanıtların kavramsal olarak anlamsız olduğu işaretlemeler ile birlikte sorulardan birinin veya her ikisinin boş bırakıldığı işaretlemeler "diğer yanıt" olarak kategorize edilmiştir.

“Kavram Yanılgısı Belirleme Testi”nde yer alan 18 soru için öğrencilerin vermiş olduğu yanıtlar Tablo 2'de birinci soru için yapılan gruplandırma işlemine benzer şekilde gruplandırılmıştır. Herbir soru için öğrencilerin "doğru kavram", "kavram yanılgısı" ve "diğer yanıt" kategorisinde toplanma yüzdeleri hesaplanmıştır. Aynı kavram ile ilgili olan sorular ise birlikte değerlendirilmiştir. Örneğin testin 4 . ve 11 . soruları radyasyon ile ilgilidir. $\mathrm{Bu}$ kavramla ilgili olarak öğrenci yanıtlarının 4. soru için \%36's1 “doğru kavram”, \%16'si "kavram yanılgısı", \%47'si “diğer yanıt" kategorisinde toplanmıştır. 11. soru için ise \%26'sı “doğru kavram", \%35'i kavram yanılgısı, \%39'u diğer yanıt kategorisinde toplanmıştır. Öğrencilerin 4. ve 11. soru için kategorilerdeki yanıt yüzdelerinin ortalaması alınarak ("doğru kavram" \%31, "kavram yanılgısı" \%26 ve "diğer yanıt" \%43) radyasyon kavramı ile ilgili tek bir dağılım yüzdesi oluşturulmuştur. Bu şekilde testte yer alan tüm konular ile ilgili kategoriler belirlenmiş ve yanıtların kategorilere dağılım yüzdeleri grafik ile sunulmuştur.

\subsubsection{Kavram Yanılgısı için Analiz}

"Kavram Yanılgısı" kategorisinde toplanan yanıtlar derinlemesine incelenmiştir. "Kavram yanılgısı" kategorisinde yer alan yanıtlar tek tek incelenmiş ve öğrencilerin bu kavram yanılgılarında toplanma yüzdeleri hesaplanmıştır. $\mathrm{Bu}$ şekilde birçok kavram yanılgısı tespit edilmiştir. Fakat araştırmada kavram yanılgısı testinde yer alan her bir soru için dağılım yüzdesi en yüksek olan kavram yanılgılarına yer verilmiştir. Bu kavram yanılgıları tablo şeklinde sunulmuştur. Öğrencilerle yapılan görüşmelerde belirlenen kavram yanılgıları da benzer şekilde sunulmuştur. Ayrıca her bir ölçme aracından elde edilen kavram yanılgıları bir arada incelenmiş ve öğrencilerin örnek cümleleri ile birlikte sunulmuştur.

\section{Araştırma Sonuçları ve Tartışma}

Araştırmanın sonuçları başarı düzeyi ile ilgili bulgular, kavramsal anlama düzeyi ile ilgili bulgular ve kavram yanılgıları ile ilgili bulgular olmak üzere üç başlık altında sunulmuştur.

\subsection{Başarı Düzeyi ile ilgili Bulgular}

Kavram Yanılgısı Testinden elde edilen veriler Tablo 1'deki kriterlere göre değerlendirilmiştir. Kavram yanılgısı testinde yer alan her bir soru için öğrencilerin ortalama puanları ve puanın kavramsal düzeyi aşağıdaki tabloda yer almaktadır.

Tablo 3. Öğrencilerin Kavram Yanılgısı Testi Sonuçları

\begin{tabular}{|c|c|c|c|}
\hline Nükleer Fizik Kavramı & $\begin{array}{l}\text { Soru } \\
\text { Numarası }\end{array}$ & $\begin{array}{l}\text { Ortalama } \\
\text { Puan }\end{array}$ & $\begin{array}{l}\text { Kavramsal } \\
\text { Düzey }\end{array}$ \\
\hline \multirow[t]{5}{*}{ Radyoaktif Materyal } & 1 & 1.49 & Orta \\
\hline & 2 & 1.38 & Orta \\
\hline & 5 & 0.91 & Düşük \\
\hline & 8 & 0.25 & Düşük \\
\hline & 10 & 0.78 & Düşük \\
\hline Radyoaktivite & 12 & 0.55 & Düşük \\
\hline \multirow[t]{2}{*}{ Radyasyon } & 4 & 1.25 & Orta \\
\hline & 11 & 0.88 & Düşük \\
\hline \multirow[t]{2}{*}{ Nükleer Reaksiyon } & 7 & 0.59 & Düşük \\
\hline & 16 & 0.75 & Düşük \\
\hline Yar1 Ömür & 9 & 1.07 & Orta \\
\hline \multirow{2}{*}{$\begin{array}{l}\text { Radyoaktif Işımalar: Alfa } \\
\text { Işıması }\end{array}$} & 3 & 0.78 & Düşük \\
\hline & 13 & 0.49 & Düşük \\
\hline $\begin{array}{l}\text { Radyoaktif Işımalar: Beta } \\
\text { Işıması }\end{array}$ & 6 & 0.96 & Düşük \\
\hline \multirow{2}{*}{$\begin{array}{l}\text { Radyoaktif } \\
\text { Gama Işımasıalar: }\end{array}$} & 14 & 0.76 & Düşük \\
\hline & 15 & 0.85 & Düşük \\
\hline $\begin{array}{l}\text { Çekirdek Tepkimeleri: } \\
\text { Fisyon Reaksiyonu }\end{array}$ & 18 & 0.87 & Düşük \\
\hline $\begin{array}{l}\text { Çekirdek Tepkimeleri: } \\
\text { Füzyon Reaksiyonu }\end{array}$ & 17 & 0.35 & Düşük \\
\hline Toplam Ortalama Puan & & 14.93 & Düşük \\
\hline
\end{tabular}

Tablo 3'deki veriler incelendiğinde, öğrencilerin 4 soru için "orta düzey", 14 soru için ise "düşük düzey" başarı kategorisinde toplandığı görülmektedir. Ayrıca öğrenciler testin bütününden aldıkları ortalama puan ile "düşük düzey başarı" kategorisinde değerlendirilmiştir.

\subsection{Kavramsal Anlama Düzeyi ile ilgili Bulgular}

Aşağıdaki resimde öğrencilerin "Kavram Yanılgısı Belirleme Testi"ne verdikleri yanıtların her bir kavram için "doğru kavram", "kavram yanılgısı" ve "diğer yanıt" kategorilerine dağılım yüzdelerine yer verilmiştir. 
Resim 1. Yanıtların Kavramsal Kategorilere Dă̆ılımı

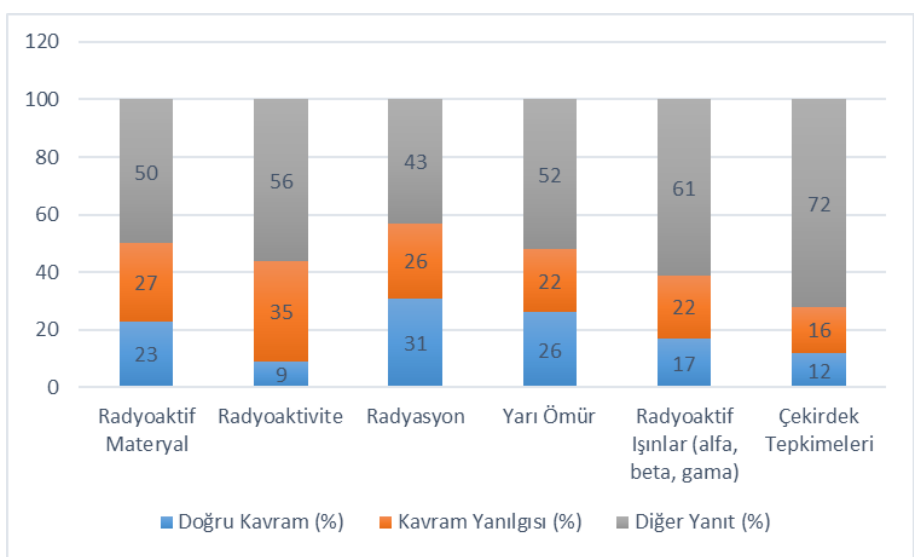

Resim 1 incelendiğinde öğrencilerin tüm kavramlar için en fazla "diğer yanıt" kategorisinde toplandığı anlaşılmaktadır. Diğer yanıt boş bırakılan veya bilimsel olarak anlamsız yanıt kombinasyonlarını içermektedir. Öğrencilerin tüm kavramlar için en fazla bu kategoride toplanmaları ögrencilerin nükleer fizik kavramları ile ilgili yeterli kavramsal anlamaya sahip olmadıkları şeklinde yorumlanmıştır. Çünkü öğrencilerin doğru bir kavram veya bir kavram yanılgısına sahip olabilmeleri için belirli düzeyde bilgi birikimine sahip olmaları gerekir (Yağbasan ve Gülçiçek, 2003).

Öğrencilerin doğru yanıtlarının kavram yanılgılarından fazla olduğu kavramlar şunlardır; Radyasyon ve yarı ömür. Öğrencilerin kavram yanılgılarının doğru yanıtlarından fazla olduğu kavramlar ise şunlardır; radyoaktif materyal, radyoaktivite, radyoaktif 1şınlar ve çekirdek tepkimeleri. Bu bulgu öğrencilerin radyasyon ve yarı ömür kavramlarını nükleer fizik ile ilgili diğer kavramlara göre daha iyi öğrendikleri şeklinde değerlendirilmiştir.

\subsection{Kavram Yanılgıları için Bulgular}

Bu bölümde Resim 1'de "kavram yanılgısı” kategorisi içinde yer alan kavram yanılgıları detaylı olarak incelenmiştir.

\subsubsection{Radyoaktif Materyal, Radyoaktivite ve Radyasyon Kavramlart ile İlgili Kavram Yanulgılart}

Aşağıdaki tabloda öğrencilerin radyoaktif materyal, radyoaktivite ve radyasyon kavramları ile ilgili ön plana çıkan kavram yanılgıları yer almaktadır.
Tablo 4. Radyoaktif materyal, radyoaktivite ve radyasyon ile ilgili kavram yanılgılart

\begin{tabular}{|c|c|c|c|}
\hline \begin{tabular}{|c|} 
Soru \\
Numarası \\
\end{tabular} & Kavram Yanılgısı & $\begin{array}{c}\text { Yanit } \\
\text { Kombinasyonu } \\
\end{array}$ & $\begin{array}{c}\text { Yanit } \\
\text { yüzdesi }\end{array}$ \\
\hline \multicolumn{4}{|c|}{ Radyoaktif Materyal } \\
\hline 1 & $\begin{array}{l}\text { Çok yüksek sıcaklığa } \\
\text { maruz bırakılan bir } \\
\text { radyoaktif madde } \\
\text { radyoaktif özelliğini } \\
\text { kaybeder. }\end{array}$ & $\mathrm{AB}$ & 13 \\
\hline 2 & $\begin{array}{l}\text { Radyoaktif bir atomun } \\
\text { kararlı bir atomla yaptığ } 1 \\
\text { bileşik radyoaktif özellik } \\
\text { göstermez. }\end{array}$ & AA & 13 \\
\hline 5 & $\begin{array}{l}\text { Radyoaktif maddeler } \\
\text { ancak dişardan bir etki } \\
\text { olursa radyasyon } \\
\text { yayarlar. }\end{array}$ & $\mathrm{AC} / \mathrm{BC}$ & 36 \\
\hline 8 & $\begin{array}{l}\text { Bir maddenin radyoaktif } \\
\text { olma özelliğini o } \\
\text { maddenin fiziksel ve } \\
\text { kimyasal özellikleri } \\
\text { etkiler. Çünkü fiziksel ve } \\
\text { kimyasal değişmeler } \\
\text { sonucunda atomun hem } \\
\text { iç hem de dış yapısı } \\
\text { değişir. }\end{array}$ & $\mathrm{AD}$ & 39 \\
\hline 10 & $\begin{array}{l}\text { Yapay radyoaktif } \\
\text { maddeler doğal } \\
\text { radyoaktif maddelere } \\
\text { göre insan sağlı̆̆ı için } \\
\text { daha zararlıdır. }\end{array}$ & $\mathrm{BD}$ & 36 \\
\hline \multicolumn{4}{|c|}{ Radyoaktivite } \\
\hline 12 & $\begin{array}{l}\text { Kararsız atomlar } \\
\text { radyoaktivite olayı } \\
\text { sonucunda son } \\
\text { yörüngelerindeki } \\
\text { elektronlarını salarak } \\
\text { kararlı hale geçer. } \\
\end{array}$ & AA & 35 \\
\hline \multicolumn{4}{|l|}{ Radyasyon } \\
\hline 4 & $\begin{array}{l}\text { Düşük enerjili radyoaktif } \\
\text { 1şımaya maruz bırakılan } \\
\text { canlılar, radyoaktif } \\
\text { kaynaktan uzaklaşsa bile } \\
\text { radyoaktif hale gelir. } \\
\text { Çevresine radyasyon } \\
\text { yaymaya başlar. Çünkü } \\
\text { radyasyon canlının } \\
\text { hücreleri tarafından } \\
\text { emilir daha sonra salınır. }\end{array}$ & $\mathrm{AD}$ & 16 \\
\hline 11 & $\begin{array}{l}\text { Bütün radyasyon çeşitleri } \\
\text { zararlıdır. Çünkü bütün } \\
\text { radyasyon çeşitlerinin } \\
\text { kaynağı radyoaktif } \\
\text { maddelerdir. }\end{array}$ & AA & 35 \\
\hline
\end{tabular}

Radyoaktif materyal, radyoaktivite ve radyasyon kavramları ile ilgili öne çıkan kavram yanılgıları Tablo 4'te yer almaktadır. Araştırmada radyoaktif materyal ile ilgili beş, radyoaktivite ile ilgili bir ve radyasyon ile ilgili iki kavram yanılgısı belirlenmiştir. Radyoaktif materyal ile ilgili en sık rastlanan kavram yanılgısı şu şekildedir; "Bir maddenin radyoaktif olma özelliğini o maddenin fiziksel ve kimyasal özellikleri etkiler. Çünkü fiziksel ve kimyasal değişmeler sonucunda atomun hem iç hem de dış yapısı değişir. Radyoaktivite ile ilgili en sık rastlana kavram yanılgısı şu şekildedir; "Kararsız atomlar radyoaktivite olayı sonucunda son yörüngelerindeki elektronlarını salarak kararlı hale geçer". Radyasyon kavramı ile ilgili en s1k rastlanan kavram yanılgısı ise 
şu şekildedir; "Bütün radyasyon çeşitleri zararlıdır. Çünkü bütün radyasyon çeşitlerinin kaynağı radyoaktif maddelerdir”.

Öğrencilerle yapılan görüşmelerde de radyoaktif materyal ile ilgili kavram yanılgılarına rastlanmıştır. Bu kavram yanılgıları, yanıt sıklığı ve örnek öğrenci görüşleri ile birlikte aşağıdaki tabloda yer almaktadır.

Tablo 5. Yarı yapılandırılmış görüşmeler ile elde edilen radyoaktif materyal, radyoaktivite ve radyasyon ile ilgili kavram yanılgilart

\begin{tabular}{lcc}
\hline \multicolumn{1}{c}{ Kavram Yanılgıları } & $\begin{array}{c}\text { Öğrenci } \\
\text { Sayısı }\end{array}$ & $\begin{array}{c}\text { Yüzde } \\
(\boldsymbol{\%})\end{array}$ \\
\hline Tüm radyoaktif maddeler güçlü ve tehlikelidir. & 4 & 100 \\
\hline $\begin{array}{l}\text { Yapay radyoaktif maddeler doğal radyoaktif } \\
\text { maddelerden daha zararlıdır. }\end{array}$ & 4 & 100 \\
\hline $\begin{array}{l}\text { Radyoaktivite sırasında çekirdeğin proton ve } \\
\text { nötron sayısı değişmez. Radyoaktivite elektron } \\
\text { alışverişi ile gerçekleşir. }\end{array}$ & 4 & 100 \\
\hline $\begin{array}{l}\text { Radyoaktif madde 1şıma yaptığında kimyasal } \\
\text { yapısı bozulmaz. }\end{array}$ & 3 & 75 \\
\hline $\begin{array}{l}\text { Radyoaktif 1şımaya maruz kalan bir canlı } \\
\text { radyoaktif özellik kazanır. }\end{array}$ & 3 & 75 \\
\hline $\begin{array}{l}\text { Radyasyon yayan cihazlar radyoaktif } \\
\text { materyallerden üretilir. }\end{array}$ & 2 & 50 \\
\hline
\end{tabular}

$\mathrm{Bu}$ kavram yanılgılarına ek olarak "Yarı Yapılandırılmış Görüşmeler"de öğrencilerin radyoaktif materyaller ile ilgili olumsuz bir algıya sahip olduğu belirlenmiş̧tir. Öğrenciler tüm radyoaktif maddelerin güçlü ve tehlikeli olduğunu düşünmektedir. Bu görüşe sahip bir öğrenci ile yapılan görüşmede öğrenci düşüncelerini şu şekilde ifade etmiştir.

A: Radyoaktif materyaller ile ilgili düşüncelerini paylaşır misin?

Ö1: Radyoaktif materyaller güçlü ve tehlikelidir. Bu nedenle bu materyallerden korunmamı gerekir.

A: Să̆lı̆̆ımız için zararı olmayan radyoaktif materyal var midır?

\section{Ö2: Bildiğim kadarıla yoktur.}

Araştırmada karşılaşılan ve yaygın olan kavram yanılgılarından bir diğeri yapay radyoaktif maddelerin doğal radyoaktif maddelerden daha zararlı olduğudur. Bu düşünceye sahip bir öğrenci düşüncesini şu şekilde ifade etmiştir.

A: Yapay ve doğal radyoaktif materyallerden söz ettin. Bu iki radyoaktif materyali insan sağglı̆ $\breve{l}$ açısından değgerlendirdiğinde neler söyleyebilirsin?

Ö3: Yapay radyoaktif materyallerde daha fazla radyasyon var. İnsan vücudu doğal radyoaktiviteye uzun süre maruz kaldı $\breve{g}$ için direnç kazanmıştır. Fakat insan vücudu yapay radyoaktiviteye karşı dirençli değildir.

$\mathrm{Bu}$ öğrencinin ifadelerinden anlaşılacağı gibi öğrenci doğal ve yapay radyoaktiviteyi doğal ve yapay kelimelerinin çağrıştırdığ 1 genel algıya göre yorumlamaktadır. Bu genel algıya göre yapay olan doğal olana göre daha zararlıdır. Öğrencilerin radyasyonun insan sağlığına etkileri ile ilgili bir başka düşüncesi ise radyoaktif ışımaya maruz kalan bir canlının radyoaktif bir kaynak gibi ışıma yaptığı görüşüdür. Bir öğrenci bu düşüncesini şu cümlelerle açıklamıştır.

Ö2: Işımaya maruz kalan hastalar genellikle ışıma yapar. Bu nedenle bu hastalara çocuklara sarlmayın denir. Bu hastalardan bir gün boyunca çocuklardan uzak durması istenir. Örneğin e-ISSN: 2148-2683 tomografi çektiren birinin bir süre başkalarından uzak durması gerekir.

Görüşmelerde öğrencilerin radyoaktif materyal ile ilgili olumsuz algılarının yanı sıra radyoaktivitenin kökeni ile ilgili yanlış bir algıya sahip oldukları tespit edilmiştir. Öğrenciler radyoaktivitenin elektron alışverişi ile gerçekleşen bir olay olduğu düşünmektedir. Bu görüşe sahip bir öğrenci düşüncelerini aşağıdaki cümleler ile ifade etmiştir.

Ö1: Radyoaktivite elektron geçişi ile ilgili bir özelliktir. Elektron bir üst enerji seviyesinden alt enerji seviyesine geçerken radyasyon yayar...

Bu görüş öğrencinin radyoaktif 1şımayı uyarılmış bir atomun foton yayarak daha düşük bir enerji seviyesine geçişi ile karıştırmaktadır. Öğrencilerin, radyoaktif materyal radyasyon yayan cihaza denir şeklindeki görüşünün temelinde bu düşünce vardır. Örneğin radyoaktif madde 1şıma yaptığında kimyasal yapısı bozulmaz görüşünü savunan bir öğrenci aşağıdaki açıklamayı yapmıştır.

Ö1: Röntgen çekimi sırasında x tüpünü sürekli kullanıyoruz. Yapısı değişseydi bir kez kullanırdık.

Öğrencinin ifadelerinden anlaşıldığı gibi öğrenci röntgen cihazlarından yayılan $\mathrm{X}$-1şınlarının radyoaktivite sonucu oluştuğunu düşünmektedir.

Radyasyon yayan cihazların radyoaktif materyalden üretildiği görüşünü savunan bir öğrenci ise aşağıdaki açıklamayı yapmıştır.

Ö1: Radyoaktif materyal radyasyon yayan cisimlere denir. Materyal alet gibi bir şeydir. Görüntüleme cihazlarının içinde radyoaktif madde vardır. $x$-ışınını bu madde verir.

Yukardaki açıklamayı yapan bu öğrenci röntgen cihazından yayılan X-1şınının radyoaktif bir kaynaktan yayıldığı görüşüne sahiptir. Bu öğrenci bu konudaki düşüncesini aşağıdaki cümleler ile açıklamıştır.

Ö1: "Röntgen çekilen bir ortamda ışınlar odanın duvarlarına çarparak odanın içinde kalır. Işınların duvarlara çarpması sonucu hızı sürekli azalır ve en son toz bulutuna dönüşür. Odadaki hava sirkülasyonu ile bu radyasyon dışarı atılır böylece odadaki radyasyon mümkün olan en az seviyeye çekilir. Bu nedenle bizlerden hastaya doğru pozisyon vermemiz ve az sayıda çekim yapmamı istenir. Böylece odada biriken radyasyondan daha az etkilenmiş oluruz."

Yarı yapılandırılmış görüşme sonucu ortaya çıkan veriler bir arada değerlendirildiğinde öğrencilerin radyoaktif materyal kavramı ile ilgili olarak tüm radyoaktif materyaller tehlikelidir düşüncesine sahip oldukları anlaşılmaktadır. Ayrıca öğrenciler yapay radyoaktivitenin doğal radyoaktiviteden daha tehlikeli olduğunu düşünmektedir. Buna ek öğrenciler radyoaktif 1şımanın kaynağının atomun elektronlarının enerji seviyeleri arasındaki geçişi olduğu düşünmektedir.

\subsubsection{Yarı Ömür, Radyoaktif Işımalar ve Çekirdek Tepkimeleri ile İlgili Kavram Yantlgılart}

Aşağıdaki tabloda öğrencilerin yarı ömür, radyoaktif 1şımalar ve çekirdek tepkimeleri kavramları ile ilgili ön plana çıkan kavram yanılgıları yer almaktadır. 
Tablo 6. Öğrencilerin yarı ömür, radyoaktif ışınlar ve çekirdek tepkimeleri ile ilgili kavram yanılgıları

\begin{tabular}{|c|c|c|c|}
\hline $\begin{array}{c}\text { Soru } \\
\text { Numarası }\end{array}$ & Kavram Yanılgısı & $\begin{array}{c}\text { Yanit } \\
\text { Kombinasyonu }\end{array}$ & $\begin{array}{c}\text { Yanıt } \\
\text { yüzdesi }\end{array}$ \\
\hline \multicolumn{4}{|l|}{ Yarı Ömür } \\
\hline 9 & $\begin{array}{l}\text { Bir radyoaktif çekirdeğin } \\
\text { yarılanma süresi } \\
\text { çekirdeğin başlangıçtaki } \\
\text { miktarına bağlıdır. }\end{array}$ & BB & 22 \\
\hline \multicolumn{4}{|c|}{ Radyoaktif Işınlar (Alfa, Beta ve Gama Bozunması) } \\
\hline 3 & $\begin{array}{l}\text { Alfa 1şıması yapan bir } \\
\text { çekirdek sadece } \\
\text { enerjisini kaybeder başka } \\
\text { bir elemente dönüşmez. }\end{array}$ & $\mathrm{BD}$ & 21 \\
\hline 13 & $\begin{array}{l}\text { Alfa bozunması için } \\
\text { çekirdeğin radyoaktif bir } \\
\text { madde ile etkileşmesi } \\
\text { gerekir. }\end{array}$ & $\mathrm{BD}$ & 25 \\
\hline 6 & $\begin{array}{l}\text { Beta bozunmasında } \\
\text { atomun elektron } \\
\text { kabuklarındaki } \\
\text { elektronlar yayınlanır. }\end{array}$ & $\mathrm{BD}$ & 15 \\
\hline 14 & $\begin{array}{l}\text { Gama 1şınları alfa ve } \\
\text { beta 1şınları gibi girici } \\
\text { olduğu için kütlesi } \\
\text { vardır. }\end{array}$ & AA & 33 \\
\hline 15 & $\begin{array}{l}\text { Gama 1şıması yapan bir } \\
\text { çekirdeğin atom ve kütle } \\
\text { numarası değiştiği için } \\
\text { başka bir elemente } \\
\text { dönüşür. }\end{array}$ & AA & 18 \\
\hline \multicolumn{4}{|c|}{ Fisyon ve Füzyon Tepkimeleri } \\
\hline 17 & $\begin{array}{l}\text { Füzyon kararsız } \\
\text { radyoaktif çekirdeklerin } \\
\text { nötronlarla } \\
\text { bombardıman edilerek } \\
\text { iki tane kararlı } \\
\text { radyoaktif çekirdek } \\
\text { oluşturması olayıdır. }\end{array}$ & AA & 21 \\
\hline 18 & $\begin{array}{l}\text { İki çekirdeğin birleşmesi } \\
\text { için dışarıdan alınan tüm } \\
\text { enerji kullanıldığından } \\
\text { nükleer kaynaşma } \\
\text { reaksiyonlarında enerji } \\
\text { açığa çıkmaz. }\end{array}$ & $\mathrm{AD}$ & 11 \\
\hline
\end{tabular}

Yarı ömür, radyoaktif 1şınlar, fisyon ve füzyon tepkimeleri kavramları ile ilgili öne çıkan kavram yanılgıları Tablo 6'da yer almaktadır. Yarı ömür ile ilgili en sık rastlanan kavram yanılgısı bir çekirdeğin yarılanma süresinin çekirdeğin başlangıçtaki miktarına bağlı olduğudur. Radyoaktif ışınlar ile ilgili en sık rastlanan kavram yanılgısı gama 1şınlarının kütlesinin olduğudur. Fisyon ve füzyon tepkimeleri ile ilgili en sık rastlanan kavram yanılgısı ise füzyonun kararsız çekirdeklerin nötron ile bombardımanı sonucunda gerçekleștiğidir.

Öğrencilerle yapılan görüşmelerde tespit edilen kavram yanılgıları ve örnek öğrenci görüşleri aşağıda yer almaktadır.
Tablo 7. Öğrencilerin yarı ömür, radyoaktif ışınlar ve çekirdek tepkimeleri ile ilgili kavram yanılgılart

\begin{tabular}{lcc}
\hline \multicolumn{1}{c}{ Kategori } & $\begin{array}{c}\text { Öğrenci } \\
\text { Sayısı }\end{array}$ & $\begin{array}{c}\text { Yüzde } \\
(\mathbf{\%})\end{array}$ \\
\hline $\begin{array}{l}\text { Yarılanma süresi çekirdeğin } \\
\text { başlangıçtaki miktarına bağlıdır. }\end{array}$ & 3 & 75 \\
\hline Gama 1şınları kütlelidir. & 2 & 50 \\
\hline $\begin{array}{l}\text { Fisyon için gerekli enerji füzyon için } \\
\text { gerekli enerjiden daha fazladır. }\end{array}$ & 2 & 50 \\
\hline
\end{tabular}

Görüşmelerde öğrencilerin çekirdeğin yarılanma süresinin çekirdeğin başlangıçtaki miktarına bağlı olduğunu düşündükleri tespit edilmiştir. Bir öğrenci bu düşüncesini şu şekilde açıklamıştır.

Ö2: Nükleer çekirdeğin başlangıç miktarı ne kadar fazla ise yarllanma süreside o kadar fazla olur.

A: Bozunmaya uğrayan radyoaktif bir materyalin zamanla yarılanma süresi değişir mi?

Ö2: Illk başta çok çekirdek olduğu için çekirdek miktarının yarlya düşmesi için uzun bir süre geçer. Daha sonra bu süre sürekli kısalır. Örneğin ilk başta çekirdek miktarının yarıya inmesi için 6 yll geçiyorsa daha sonra 3 yıl daha sonra 1 yıl geçebilir.

A: Senin ifadelerinden anladı̆̆ıma göre bir radyoaktif izotopun sabit bir yarllanma süresi olmadı̆̆ını düşünüyorsun. Öyle mi?

Ö2: Evet. Radyoaktif materyalin bozunmayan çekirdek miktarına göre yarılanma süresi değişir.

Öğrenci çekirdeğin başlangıçtaki miktarının yarılanma süresini etkilediğini düşünmektedir. $\mathrm{Bu}$ bulgular öğrencinin nükleer çekirdekler için aktiflik kavramı ile yarılanma süresi kavramını birbirine karıştırdıklarını göstermektedir.

Görüşmelerde belirlenen bir başka kavram yanılgısı ise gama ışınlarının kütlesi olduğudur. Bu görüşe sahip olan bir öğrenci düşüncesini aşağıdaki cümlelerle açıklamıştır.

Ö4: "Gama ışınlarının kütlesi var. Fakat bu kütle alfa ve beta ışınlarının kütlesinden daha küçüktür. Bu sayede kaynaktan daha uzağa gidebilmekte ve bu ışınlar diğerlerine göre daha girici olabilmektedir."

Öğrencinin ifadelerinden anlaşıldığı gibi öğrenci gama 1şınlarının kütlesi olduğunu düşünmektedir.

Görüşmelerde belirlenen bir başka kavram yanılgısı ise fisyon için gerekli enerjinin füzyon için gerekli enerjiden daha fazla olduğudur. Bir öğrenci çekirdek reaksiyonları ile ilgili görüşlerini aşağıdaki cümleler ile açıklamıştır.

Ö3: Füzyon reaksiyonları hakkında çok fazla bilgiye sahip değilim. Fakat fisyon reaksiyonlarını biliyorum. Amerika'nın Japonya'ya attı̆̆ atom bombalarl bu reaksiyonlara örnektir. Fisyon reaksiyonlarında çok yüksek enerji açığa çıkar. Bundan daha güçlü bir enerji açı̆̆a çıkarma yöntemi olmadiğını düşünüyorum.

Öğrencinin fisyon reaksiyonları ile ilgili bilgilerinin genel kültür bilgileri olduğu anlaşılmaktadır. Ayrıca öğrenci fisyon reaksiyonu konusunda füzyon reaksiyonu konusuna göre daha fazla bilgiye sahiptir.

Yarı yapılandırılmış görüşme sonucu ortaya çıkan veriler bir arada değerlendirildiğinde öğrencilerin yarı ömür, radyoaktif 1şınlar ve çekirdek tepkimeleri ile ilgili bilgi düzeylerinin düşük 
olduğu anlaşılmıştır. Öğrenciler yarılanma süresinin çekirdeğin başlangıçtaki miktarına bağlı olduğunu ve gama 1şınlarının kütlesinin olduğunu düşünmektedir. Ayrıca öğrencilerin füzyon konusundaki bilgi düzeyi yetersizdir.

\section{Sonuç}

$\mathrm{Bu}$ araştırmada, sağlık teknikerliği programlarında öğrenim gören öğrencilerin nükleer fizik kavramları ile ilgili kavramsal anlama düzeyi ve kavram yanılgıları araştırılmıştır. Araştırmada öğrencilerin nükleer fizik kavramları ile ilgili kavramsal anlama düzeyi "düşük düzey" olarak sınıflandırılmıştır. $\mathrm{Bu}$ bulgu, araştırmanın yapıldığı meslek yüksekokulunun radyoterapi, nükleer tıp, tıbbi görüntüleme ve ameliyathane hizmetleri programlarında öğrenim gören öğrencilerinin nükleer fizik kavramlarını anlamada güçlük çektiğini göstermektedir. Öğrencilerin nükleer fizik kavramlarını anlamada güçlük çektiği başka araştırmacılar tarafindan da belirlenmiştir. Morgil vd. (2004) öğrencilerin özellikle radyoaktif bozunma ve yarılanma süresi ile ilgili doğru yanıt yüzdelerinin düşük olduğunu ifade etmiştir. Ayrıca bu araştırmada öğrencilerin aktivite, izotop, alfa ve beta bozunmaları ile ilgili eksik bilgileri olduğu belirtilmiştir. Nakiboğlu ve Tekin (2006) ise öğrencilerin radyoaktif izotop ve radyoaktif bozunma kavramları ile ilgili eksik bilgileri ve kavram yanılgıları olduğunu ifade etmiştir.

Araştırmada ayrıca öğrencilerin yanıtları "doğru kavram”, "kavram yanılgısı" ve "diğer yanıt" olarak üç kategoriye ayrılarak incelenmiştir. Öğrencilerin radyoaktif materyal, radyoaktivite, radyasyon, yarı ömür, radyoaktif ışınlar ve çekirdek tepkimeleri konularının tümünde en fazla "diğer yanıt" kategorisinde toplandığı tespit edilmiştir. "Diğer yanıt" kategorisi içinde boş bırakılan veya bir kavram yanılgısı içinde değerlendirilemeyen yanıtlar yer almaktadır. Öğrencilerin tüm kavramlar için en fazla bu kategoride toplanmaları ögrencilerin nükleer fizik kavramları ile ilgili yeterli bilgi birikimine sahip olmadıkları şeklinde yorumlanmıştır. Çünkü öğrencilerin doğru bir kavrama veya bir kavram yanılgısına sahip olmaları için belirli düzeyde bilgi birikimine ve yaşammışlığa sahip olması gerekir (Yağbasan ve Gülçiçek, 2003). Ayrıca öğrencilerin nükleer fizik kavramlarını birbiri yerine kullanmalarının (Klaassen vd., 1990) da "diğer yanıt" kategorisinde toplanmalarında etkisi olduğu söylenebilir. Buna ek olarak ögrrencilerin radyasyon ve yarı ömür kavramları için "doğru kavram" kategorisinde toplanma yüzdelerinin "kavram yanılgısı" kategorisinde toplanma yüzdelerinden fazla olduğu tespit edilmiştir. Fakat öğrencilerin radyoaktif materyal, radyoaktivite, radyoaktif 1 şınlar ve çekirdek tepkimeleri için "kavram yanılgısı" kategorisinde toplanma yüzdeleri "doğru yanıt" kategorisinde toplanma yüzdelerinden fazladır. Ayrıca öğrencilerin "doğru yanıt" kategorisinde toplanma yüzdesinin en yüksek olduğu kavram radyasyon, en düşük olduğu kavram ise radyoaktivitedir. $\mathrm{Bu}$ bulgu öğrencilerin en iyi öğrendikleri kavramın radyasyon, öğrenmede en fazla güçlük çektikleri kavramın radyoaktivite olduğunu göstermektedir. Öğrencilerin radyoaktivite kavramını öğrenmede güçlük çekmelerinin temelinde radyoaktif 1şımayı Bohr atom modeli ve enerji düzeyleri teorisini kullanarak açıklamaları yatmaktadır (Prather, 2005).

Araştırmada öğrencilerin nükleer fizik kavramları ile ilgili kavramsal anlama durumu derinlemesine incelenmiştir. Araştırmada radyoaktif materyal ile ilgili en sık rastlanan kavram yanılgısı bir maddenin radyoaktif olma özelliğinin o maddenin fiziksel ve kimyasal özelliklerine bağlı olduğudur. Bu kavram yanılgısı Mavi (2008) tarafından da tespit edilmiştir. Bu araştırmada öğrencilerin maddelerdeki doğal radyoaktiviteyi yağmur, kar, basınç ve rüzgar gibi fiziksel koşullardan etkilenen bir özellik olarak tanımladıkları ifade edilmiştir.

Araştırmada radyasyon kavramı ile ilgili en sık rastlanan kavram yanılgısı ise bütün radyasyon çeşitlerinin zararlı, güçlü ve tehlikeli olduğudur. Öğrenciler radyasyon çeşitlerinin tümünün kaynağının radyoaktif madde olduğunu ifade etmiştir. Ayrıca ögrencilere göre yapay radyoaktivite doğal radyoaktiviteden daha tehlikelidir. Araştırmanın bu bulguları öğrencilerin radyoaktivite kavramını olumsuz duygular ve korku ile özdeşleştirdiğini göstermektedir (Tezcan ve Erçoklu, 2010). Birçok araştırma benzer şekilde öğrencilerin nükleer fizik kavramlarına karşı olumsuz duygular geliştirdiğini belirlemiştir. Cooper vd. (2003) öğrencilerin nükleer enerji konusunda korkularının ve kaygılarının olduğunu ifade etmiştir. Ayrıca araştırmacılar öğrencilerin iyonlaştırıcı radyasyonun insan dokusu üzerindeki etkileri ile ilgili sınırlı bilgileri olduğunu ifade etmiştir. Millar vd. (1990) öğrencilerin radyasyonu ve radyoaktif materyali tek bir kavram olarak ele aldıklarını ve bu ortak kavramın canlılar için tehlikeli olduğunu düşündüklerini belirtmiştir. Neumann (2014) radyasyon sözcügünün öğrencilerde ağırlıklı olarak olumsuz çağrışım yaptığını ve öğrencilerin radyasyonu uzak durulması kaçınılması gereken bir şey olarak tanımladıklarını belirtmiştir. Araştırmada öğrencilerin doğal radyasyon fikrine aşına olmadıkları, birçok öğrencinin radyasyonu genellikle yapay ve insan yapımı bir şey olarak tanımladıkları vurgulanmıştır. Ayrıca araştırmada hiçbir öğrencinin radyasyonun tıpta ve nükleer santraller dışında teknolojide kullanımına değinmediği sonucuna ulaşılmıştır.

Araştırmada öğrencilerin yarı ömür ile ilgili öne çıkan kavram yanılgısı yarı ömrün çekirdeğin kararlılığına ve başlangıç miktarına bağlı olduğudur. Tezcan ve Erçoklu (2010) öğrencilerin yarılanma süresini maddenin başlangıçtaki miktarı, sıcaklığı ve fiziksel hali ile değişen bir özellik olarak tanımladıklarını ifade etmiştir. Morgil vd. (2004) öğrencilerin yarılanma süresi ile ilgili doğru yanıt yüzdesinin düşük olduğunu ve öğrencilerin yarılanma süresi ile radyoaktif maddenin kütlesi arasında bir ilişki kurduğunu tespit etmiştir. Yalçın ve Kılıç (2005) ise öğrencilerin radyoaktif bir maddenin bir yarılanma süresi sonunda radyoaktif özelliğini kaybettiğini düşündüklerini ifade etmiştir.

Araştırmanın ilginç bulgularından biri ise sağlık teknikerliği programı öğrencilerinin radyasyona maruz kalan canlıların radyoaktif kaynağa dönüşeceği yanılgısına sahip olmasıdır (Mavi, 2008). Öğrencilerin bu kavram yanılgısının staj ve klinik uygulama eğitimlerinde edindikleri deneyimlerini, eksik nükleer fizik ve görüntüleme teknikleri bilgileri ile harmanlamaları sonucu oluştuğu düşünülmektedir. Çünkü eksik nükleer fizik bilgisi bu konu ile ilgili birçok kavram yanılgısının oluşmasına sebep olmaktadır. Örneğin öğrencilerin radyoaktif 1şıma (irradiation) ve radyoaktif bulaşma (contamination) kavramlarını birbiri yerine kullanmaları radyoaktif ışıma sırasında kaynaktan çevreye radyoaktif materyal yayıldığı, radyoaktivitenin yayılabildiği, radyoaktif kaynağın elektrik alan manyetik alan gibi radyoaktif bir alana sahip olduğu, radyasyonun rüzgar ile taşındığı, radyasyonun atmosferi kirlettiği gibi düşüncelerin oluşmasına neden olmaktadır (Klaassen vd. 1990). Radyasyona maruz kalan canlıların radyoaktif kaynağa dönüşmesi ile ilgili olan kavram yanılgısını Kaczmarek vd. (1987)'de belirlemiştir. Araştırmacılar öğrencilerin bir röntgen odası içindeki nesnelerin röntgen çekimi sonrasında 1şıma yaptığına inandıklarını belirlemiştir. 
$\mathrm{Bu}$ araştımada sağlık teknikerliği programlarında öğrenim gören öğrencilerin nükleer fizik kavramları ile ilgili kavramsal anlama düzeyleri araştırılmıştır. Araştırma sonuçları ilgili alanyazınla ilişkilendirilerek detaylı bir şekilde açıklanmıştır. Bu yönü ile bu araştırma nükleer fizik kavram yanılgıları ile ilgili araştırma yapmak isteyen araştırmacılara 1şık tutacak niteliktedir. Ayrıca nükleer fizik öğretiminin bu kavram yanılgılarını giderecek içerik, materyal ve öğretim teknikleri ile planlanması durumunda, bu araştırmanın bulgularının fizik öğretmenlerine mesleki açıdan katkı sağlayacağı söylenebilir.

Araştırma bulgularına dayanarak sağlık teknikerliği önlisans programlarının öğretim programlarında yer alan temel fizik, nükleer fizik ve radyasyondan korunma gibi derslere verilen önemin artırılması önerilmektedir. Çünkü bu programlarda öğrenim gören öğrenciler mezun olduktan sonra sağlık kurumlarında radyasyon içeren ortamlarda çalışacaktır. Öğrencilerin nükleer fizik kavramları ile ilgili kavram yanılgıları meslek hayatlarında kendilerinin ve çevrelerinin radyasyon güvenliği açısından risk oluşturabilir.

\section{Kaynakça}

Ausubel, D. (1968). Educational psychology: a cognitive view. New York: Holt, Rinehart and Winston.

Ayaz, E., Karakaş, H., ve Sarıkaya, R. (2016). Sınıf öğretmeni adaylarının nükleer enerji kavramına yönelik düşünceleri: Bağımsız kelime ilişkilendirme örneği. Cumhuriyet Üniversitesi Fen Fakültesi Fen Bilimleri Dergisi, 37, 43-54.

Cooper, S., Yeo, S., and Zadnik, M. (2003). Australian students' views on nuclear issues: Does teaching alter prior beliefs? Physics Education, 38, 123-129.

Eijkelhof, H.M.C., and Millar, R. (1988). Reading about Chernobyl: The public understanding of radiation and radioactivity. School Science Review, 70, 251, 35-41.

Gilbert, J. K. (1977). The study of student misunderstandings in the physical sciences. Research in Science Education, 7, 165-171.

Greene, J. C., Caracelli, V. J. and Graham, W. F. (1989). Toward a conceptual framework for mixedmethod evaluation designs. Educational Evaluation and Policy Analysis, 11(3), 255-274.

Halim, A. S., Finkenstaedt-Quinn, S. A., Olsen, L. J., Gere, A. R., and Shultz, G. V. (2018). Identifying and remediating student misconceptions in introductory biology via writing-to-learn assignments and peer review. CBE- Life Science Education, $17(2), 1-13$.

Johnson, R. B., Onwuegbuzie, A. J., and Turner, L. A. (2007). Toward a definition of mixed methods research. Journal of Mixed Methods Research, 1(2), 112-133.

Kaczmarek R., Bednarek, D.R., and Wong R. (1987). Misconceptions of medical students about radiological physics. Health Phys., 52, 106-1077.

Karataş, F.Ö., Köse, S., ve Çoştu, B. (2003). Öğrenci yanılgılarını ve anlama düzeylerini belirlemede kullanılan iki aşamalı testler. Pamukkale Üniversitesi Ĕ̆itim Fakültesi Dergisi, 1(13), 54-69.

Klaassen, C.W.J.M., Eijkelhof, H.M.C., and Lijnse, P.L. (1990). Relating macroscopic phenomena to microscopic particles: a central problem in secondary science education. Chapter: Considering an alternative approach to teaching radioactivity. CD-Beta Press. Edit: P.L. Lijnse, P. Licht, W. de Vos, A.J. Waarlo.

Mavi, M. (2008). Lise öğrencilerinin radyasyon konusundaki kavram yanılgılarının tespiti. Yayınlanmamış yüksek lisans tezi, Süleyman Demirel Üniversitesi, Fen Bilimleri Enstitüsü, Isparta.

Millar and Gill (1996). School students' understanding of processes involving radioactive substances and ionizing radiation. Physics Education, 31(1). 27-33.
Millar, R., Klaassen, K., and Eijkelhof, H. (1990). Teaching about radioactivity and ionising radiation: an alternative approach. Physics Education, 25. 338-342.

Morgil, İ., Yılmaz, A., ve Uludağ, N. (2004). Lise kimya 2 ders kitabında yer alan radyoaktivite konusunun incelenmesi, öğrencilerin bu konudaki bilgilerinin araştırılması ve öneriler. Hacettepe Üniversitesi Eğitim Fakültesi Dergisi, 27, 206-215.

Nakiboğlu, C., and Tekin, B.B. (2006). Identifying students' misconceptions about nuclear chemistry. Chemical Education Research, 83(11), 1712-1718.

Neumann, S. (2014). What Students Think About (Nuclear) Radiation-Before and After Fukushima. Nuclear Date Sheets, 120, 166-168.

Neumann, S., and Hopf, M. (2012). Students' conceptions about 'radiation': Results from an explorative interview study of 9th grade students. Journal of Science Education and Technology, $21,826-834$.

Novak, J. D. (1993). How do we learn our lesson? Taking students through the process. The Science Teacher, 60(3), 50-55.

Özdemir, E., Çoramık, M. and Ürek, H. (2020). Determinantın of Conceptual Understanding Levels Related to Optics Concepts: The Case of Opticianry. International Journal of Education in Mathematics, Science and Technology, 8(1), 53-64.

Palacı, H., Günay, O., ve Yarar, O. (2018). Türkiye'de Radyasyon Güvenliği ve Korunma Eğitiminin Değerlendirilmesi. Avrupa Bilim ve Teknoloji Dergisi, 14, 249-254.

Palmer, D.H. (1999). Exploring the between students' scientific and nonscientific conceptions. Science Education, 83, 639-653.

Prather, E. (2005). Students' beliefs about the role of atoms in radioactive decay and half-life. Journal of Geoscience Education, 53(4), 345-354.

Riesch, W. and Westphal, W. (1975) Modellhafte Schülervorstellungen zur Ausbreitung radioactiver Strahlung. Der Physikunterricht. 9(4). 75-85.

Tezcan, H., ve Erçoklu, H.F. (2010). Geleneksel anlatım ve yapılandırıcı yaklaşımın radyoaktivite öğretiminde başarıya etkilerinin karşılaştırılması ve ilgili yanlış kavramaların giderilmesindeki etkileri. Türk Ĕ̈itim Bilimleri Dergisi, 8(1), 201-225.

Yağbasan, R., ve Gülçiçek, Ç. (2003). Fen öğretiminde kavram yanılgılarının karakteristiklerinin tanımlanması. Pamukkale Üniversitesi Ĕ̈itim Fakültesi Dergisi, 1(13), 102-120.

Yalçın, A., ve Kılıç, Z. (2005). Öğrencilerin yanlış kavramları ve ders kitaplarının yanlış kavramlara etkisi örnek konu: radyoaktivite. GÜ, Gazi Ĕ̌gitim Fakültesi Dergisi, 25(3), 125-141.

Yıldırım, S. A., ve Kurt, B. (2018). Lise ve üniversite radyoloji öğrencilerinin radyasyon güvenliği hakkında bilgi düzeyleri ve tutumları. Să̆lık Akademisyenleri Dergisi, 5(4), 311-317.

Yumuşak, A., Maraş, İ., ve Şahin, M. (2016). Radyoaktivite konusunda kavram yanılgılarını belirlemeye yönelik iki aşamalı bir teşhis testinin geliştirilmesi. Mersin Üniversitesi Eğitim Fakültesi Dergisi, 12(3), 810-828.

Yüksel, A. (2018). Sağl1k hizmetleri meslek yüksekokulu öğrencilerinin uygulamalı derslere ilişkin görüşleri. Săgllk Hizmetleri ve Eğitimi Dergisi, 2(2), 72-77. 